This is not the version of record. The full published version of: Baverstock, Alison and Steinitz, Jackie (2019) What President Trump has shown us about choosing a subject for political biography. Logos, 30(2), pp. 7-11. can be found at https://doi.org/10.1163/18784712-03002002 


\section{What President Trump has shown us about choosing a subject for political biography}

\section{Alison Baverstock and Jackie Steinitz}

A significant side-effect of President Trump's White House arrival is the impact he has had on publishing about politics; both sales of existing books and new titles are burgeoning at the moment. Journalist John Goodrich of CGTN Digital got in touch to ask about why this might be, and what the high sales of books about the current incumbent in particular have to say about the growing public appetite for books about politics. His article (Goodrich, 2019) got us thinking.

Of course, it's very common for politicians to write a book in order to bring themselves to wider public attention. Barack Obama $(1995 ; 2006)$ and Hillary Clinton $(2003 ; 2014)$ had two titles apiece by the time they sought office. For publishers, given the significant investment costs, it's a matter of spotting the winners, as the cogitations of passed-over leaders are not particularly saleable. But what, we pondered, can we learn specifically from the publishing history of President\#45 that might be of relevance to future commissioning decisions? We came up with three rules, and a formula.

Rule One: Press interest is really important regardless of whether it is positive or negative.

Publishing played an interesting role in the rise of Donald Trump. It was the experience of being written about negatively (Mayer, 2016) that first propelled his name into wider consciousness. In 1985 journalist Tony Schwartz wrote such a fierce attack on him that it ended up being the cover story of New York magazine. Rather than being frustrated by such coverage, Trump was delighted by the prominence - and invited Schwartz to meet him. They discussed what he might write next, as Trump had already been offered a contract to write his autobiography.

Schwartz thought Trump too young to write his autobiography (he was only 38 at the time) and suggested he should rather write a book on 'The Art of the Deal' as the public were fascinated by his deal-making abilities. It was agreed that Schwartz would write it, in collaboration with Trump, but finding it impossible to gain time and attention from his subject, a decision was subsequently made that Schwartz would rather follow him around in order to capture his thoughts and listen in to his phone calls. This was not entirely satisfactory but did mean the book got finished. The book was published in 1987 and became an international bestseller (although not "the No. 1 selling business book of all time" as Trump repeatedly claimed on the campaign trail). Thus the learning from this Rule One - is that press interest in the subject is vital, and that a negative press can be just as effective as a positive one.

Rule Two: The subject of the book must be actively competitive about driving book sales. In the run up to the 2016 Republican convention, campaign funds were used to buy 3,500 copies of Trump's more recent 'Crippled America: How to make America great again' according to Jane Mayer (Mayer, 2016). These were bought from bookseller Barnes \& Noble for distribution via the delegate Convention goody bags, along with a MAGA hat, a packet of tissues and other essential items. It would have been more usual for stock to be negotiated as a bulk deal from the author's publishers, but only titles bought from bookstores count for the bestseller lists. It is debatable whether buying from a bookstore, and thus author royalties being paid, broke campaign rules. 
So Rule Two is that the subject must be interested in the physical sale of the books, not just happy it exists to promote their wider message. Publicists who have listened frustrated as interviewees drone on about their values and expertise, but fail to mention the title of the book, spotted this long ago.

\section{Rule Three: The subject must be visible; controversy is really important in effective political} publishing. Forget the traditional mantra about only commissioning the autobiographies of those who win approval rather than merely attention. The president's repeated rubbishing of books about him has actively contributed to their sale. Publishers have long known that the banning of a book tends to be very helpful way of getting it noticed. Both DH Lawrence's Lady Chatterley's Lover (subject of an obscenity trial in 1960) and Peter Wright's 1988 Spycatcher (which the UK government sought to ban) achieved considerable notoriety in the process, which significantly boosted sales. But given that Trump first rose to prominence through his very positive response to very negative feedback, maybe fanning the flames is just another strategy to get people talking about him and buying related books.

As we worked through the various issues involved in effective political publishing we pondered whether they could be structured into a process. We came up with an equation - The BS Formula, (we liked the happy coincidence of our initials) - which hope might generate useful discussions within the industry in future when considering investment in political biography/autobiography. Before presenting it however, we must begin with a disclaimer and some caveats. This is presented very much tongue-in-cheek. We are not offering a magic guide to predicting sales, and we are very aware that none of variables we suggest should be considered are directly measurable. Our modest aim is rather to offer a platform for discussion, and perhaps a basis to be used in planning meetings at which different publishing options are weighed up and associated risks are considered.

\section{The BS Formula for estimating likely publishing success in the field of biography and autobiography}

We begin by breaking our formula down into three parts, which will be assembled together at the end.

\section{Proxy for current potential market size}

There are essentially three groups who would consider reading/buying a biography on a particular person (the subject): people who are positively attracted to that subject (and we will refer to the number of these as F - the "for" group); those who are against (A), and those who are neutral (N) but will consider reading the book, either as they are buying for others (e.g. librarians) or because they are studying the subject, perhaps as students, academics or journalists. Each of these groups will have a likelihood to actually buy the book, which we will denote as $L_{f}, L_{a}$ and $L_{n}$ respectively. These likelihoods will probably be different; in most instances we would expect greater uptake by those who are attracted to the subject rather than against, while the likelihood of the neutral group to buy will be influenced by the size of both the for and against groups. To make things easier when considering the values to assign to each likelihood we will express it as a percentage (e.g. 5\%) but then compensate for this by dividing by 100 in the formula. 
Our proxy for potential market size is thus: $\frac{\left(F * L_{f}\right)+\left(A * L_{a}\right)+\left(N * L_{n}\right)}{100}$

i.e. it is sum of the size of each of the three groups multiplied (shown by an asterisk *) by the likelihood of each group actually purchasing the book. A full list of the variables is shown at the bottom of the article.

\section{Modifying Factors}

There will be also be a number of modifying factors which will impact on the extent to which the book will be a success now and in years to come. Five are considered here, and each should be scored on a scale from 1 (low) to 10 (high). The first factor derives from rule two above. Specifically there is a push factor $(\mathrm{P})$ which relates to how likely the subject is to promote the books either through an approach similar to that followed by Trump, or through acceptance of the need to do so through hard graft. Secondly there is a need to get the subject at just the right stage in their career; we have called this the Goldilocks factor $(\mathrm{G})$ as ideally they should be not too young/new, not too passé. Thirdly there is the long tail (T) to consider; how likely is the subject's appeal likely to last in to the future. Will there be a long tail to its sales? Fourth is the risk of the subject; will they be consistent $(C)$ to their core values? If the subject is outrageous from the outset then ongoing attention-grabbing behaviour will be expected, but if their core values are more virtuous/domestic/conventional then deviation from this could compromise the saleability of the work. Lastly we consider enjoyability (E); the extent to which the book is a good read - and likely to be recommended/loaned by previous readers/purchasers.

Since we have suggested that each of these five factors is scored out of 10 (on the basis that conceptually this is the easiest approach) we need at the end to divide our score by 100,000 (as this is $10 * 10 * 10 * 10 * 10$ )

Modifying Factors $=\frac{P * G * T * C * E}{100,000}$

\section{Dilution effect}

Lastly we need to include a measure for dilution effect which takes into account both the number of books already in the space (D) and the extent (scoring from 1 to 10 ) to which the target audience may be addicts/repeat purchasers $(R)$ of books on the subject. As an example of this in practice, The Queen, for example, may score highly on $\mathrm{R}$ as there are people who will avidly buy every book about her. Since the scoring of $R$ is out of 10 we need to include a division by 10 and we have recommended taking the square root of the number of books already published $(\sqrt{D})$ as mathematically this will dampen the effect of it.

Dilution effect $=\frac{R}{10 * \sqrt{D}}$ 


\section{The BS Score}

The final calculation involves multiplying the three components together. Thus it can either be written like this:

BS Score $=$ Proxy for market size $*$ Modifying factors $*$ Dilution effect

where the calculations for each factor are as described as above. Or it can be written in its full all-inone glory as shown at the bottom of the article. Our suggestion would be to use a spreadsheet which explicitly calculates each of three components as this will help in the associated discussions.

Perhaps the key point to consider when interpreting results is that the actual score is not important as each person/group may calibrate the scoring systems differently. Rather the scores need to be interpreted relative to other scores you have produced. You could thus take a biography of Trump as a benchmark and score him relative to your potential benchmark, or you could consider several of your options alongside each other. The most important thing is to generate discussion and consider all the factors.

BS Score $=\frac{\left(\left(F * L_{f}\right)+\left(A * L_{a}\right)+\left(N * L_{n}\right)\right) *(P * G * T * C * E) * R}{100,000,000 * \sqrt{D}}$

where:

$\mathrm{F}, \mathrm{A}, \mathrm{N}=$ For, Against, Neutral: The number of people in each group who might be interested in a biography $\mathrm{L}_{\mathrm{f}} \mathrm{L}_{\mathrm{a}}, \mathrm{L}_{\mathrm{n}}=$ Likelihood (as a \%) of the number in each group actually buying the book

$\mathrm{P}=$ Push factor: How likely is the subject to actively promote the books

$\mathrm{G}=$ Goldilocks factor: Not too young or new / not too passé

$\mathrm{T}$ = Tail: Will the subject's appeal likely last? Will the book have a long tail?

$\mathrm{C}=$ Consistency factor: How likely subject is to remain true to their brand values

$\mathrm{E}$ = Enjoyability: The extent to which the book is a good read

$\mathrm{R}=$ Repeat buying/addiction factors: factor denoting extent to which people will buy multiple books on the subject

D = Dilution factor (number of books on subject already/about to be published).

In conclusion, while we are not claiming our formula has universal relevance for biography-commissioning, or that this is a fully tested approach, it does offer a useful checklist of considerations that can be thought through before assuming risk. Presented as a spreadsheet, it could have particular relevance.

Pleasingly, others have agreed. Alan Samson, Chairman and Publisher of Weidenfeld and Nicolson, and one of the most experienced commissioning editors for biography in the publishing industry, commented: "Alison and Jackie's mathematical model for the future of publishing about politics is a new way of looking at the genre. It has the ring of truth, and is an inventive and original piece of analysis. It also affirms 
my sense that the narrative arc and the quality of storytelling is just as important in this area of biography as any other, and that a work of political career management with packaged anecdotes is no substitute for candour and an awareness of serious obstacles not always overcome".

\section{References:}

Clinton, H. (2003). Living History. New York: Simon and Schuster.

Clinton, H. (2014). Hard Choices. New York: Simon and Schuster.

Goodrich, J. (2019). How Trump came to dominate the political book market, CGTN, $13^{\text {th }}$ February 2019. https://news.cgtn.com/news/3d3d514e7a496a4e32457a63335666d54/index.html

Lawrence, D.H. (1960). Lady Chatterley's Lover. London: Penguin.

Mayer, J. (2016). 'Donald Trump's Ghostwriter tells all.' New Yorker, https://www.newyorker.com/magazine/2016/07/25/donald-trumps-ghostwriter-tells-all

Nuzzi, O. and Collins, B. (2016). 'Donald Trump Used Campaign Donations to Buy $\$ 55,000$ of His Own Book' The Daily Beast https://www.thedailybeast.com/donald-trump-used-campaign-donations-tobuy-dollar55000-of-his-own-book

Obama, B. (1995). Dreams from my father. New York: Random House.

Obama, B. (2006). The Audacity of Hope. New York: Random House.

Trump, D.J., and Schwartz, A. (1987). The art of the deal. New York: Random House.

Trump, D.J. (2016). Crippled America: How to make America great again. New York: Simon and Schuster.

Wright, P. and Greengrass, P. (1988). Spycatcher. London: Bantam Doubleday. 